\title{
Imbalance of nutritional substances of the soil at the modern stage of development of agricultural production in Russia
}

\section{Viktor V. Kidin a , Alexandr E. Shibalkin b, Maria V. Kagirova ${ }^{\text {b,* }}$}

\author{
a Department of Agronomic and Biological Chemistry and Radiology, Russian State Agrarian University-Moscow \\ Timiryazev Agricultural Academy, Moscow, Russia \\ b Department of Statistics and Econometrics, Russian State Agrarian University-Moscow Timiryazev Agricultural \\ Academy, Moscow, Russia
}

\section{Article Info}

Received : 05.05.2018

Accepted : 28.03.2019

\begin{abstract}
The paper is devoted to the analysis of changes in the gross harvest of crops from 2008 to 2017. Nutrient removal volumes according to their types with the yield of main commercial crops, including 1 hectare of each crop area are calculated. Volumes of removal by type of nutrients are established. The removal of nutrients with the yield and the application of mineral and organic fertilizers when growing major crops are compared. The size of the nutrient removal over their application in general, including the main crops and types of nutrients is estimated. Proposals to improve the effective soil fertility by increasing the use of fertilizers are formulated. The authors consider ways of these proposals implementation.
\end{abstract}

Keywords: Gross yield, arable area, productivity of land, nutrients, fertilizers, nutrient balance, natural fertility, export of mineral fertilizers, grain exports.

(C) 2019 Federation of Eurasian Soil Science Societies. All rights reserved

\section{Introduction}

From a comparison of data for two five-year periods (2008-2012) and (2013-2017) it is clear that the gross harvest of most agricultural crops in Russia has increased significantly (Table 1).

More noticeable is the growth in gross yield for sunflower, cereal crops, primarily for corn, and also for sugar beet. The growth rates for vegetables and potatoes are much lower, presumably, because the bulk of the production of these crops is in the households, where the increase in gross harvest was less intense than in the other categories of farms.

The direct components of the gross harvest are the acreage in which crops were cultivated, and their productivity. Let's turn first to the acreage. The acreage of corn and sunflower expanded to the greatest extent in the second five-year period. However, the acreage of these crops has expanded to a much lesser extent than the growth of gross harvests for these crops. For the main grain crops (wheat and barley), the size of the acreage has increased by no more than $2.5 \%$. For sugar beet, the arable area has even decreased. At the same time, as can be seen from table 1, gross harvest increased: by $14.3 \%$ for barley, by $27.6 \%$ for wheat, by $27.2 \%$ for sugar beet. As for the potato, the area of planting of this crop has decreased, due to its reduction in the household farms; the area for vegetables slightly increased with their stable sizes in household farms, at the same time, the gross harvest of potatoes increased by $8.7 \%$, vegetables by $17.0 \%$. At the same time, as can be seen from table 1, the gross yield increased: by $14.3 \%$ for barley, by $27.6 \%$ for wheat, by $27.2 \%$ for sugar beet.

\footnotetext{
${ }^{*}$ Corresponding author.

Department of Statistics and Econometrics, Russian State Agrarian University-Moscow Timiryazev Agricultural Academy, Moscow, Russia

Tel.: + 7910464412

E-mail address: kagirovamary@gmail.com

e-ISSN: 2147-4249

DOI: $10.18393 /$ ejss.551268
} 
A comparative analysis of the dynamics of gross yields and acreage makes it possible to make a univocal conclusion: the increase in gross yields in the second five-year period is primarily due to the increase in crop yields. Due to the increase in crop yields, the gross yield of sugar beet, potatoes, wheat and barley is fully or almost completely increased, and for sunflower and corn by more than $2 / 3$. In connection with the revealed circumstances, the question naturally arises: What are the reasons of the growth of yield increase in Russia over the past five years? At first sight, there are numerous yield factors of various agricultural crops, given the extremely wide variety of conditions for their growth in Russia. However, in any conditions, the leading factor is the availability of nutrients for plants, which is ensured by the natural fertility of the soil and fertilization. Of course, it is impossible to discount the improvement of cultivation technology, which is reflected in the introduction of new varieties and hybrids, in higher quality tillage, in shortening the duration of the main technological operations (sowing, harvesting), in using more efficient methods and means of controlling weeds and pests. However, in our opinion, the improvement of technology in general is aimed at increasing the ability of plants to absorb nutrients, as well as other important components of the crop water and solar energy. Comparison of the obtained volumes of crop production and the nutrients used for this is done through the construction of nutrient balances.

Table1. Gross yields, arable area and crop productivity in the Russian Federation from 2008 to 2017 by periods (Anonymous, 2018a)*

\begin{tabular}{|c|c|c|c|c|c|c|c|c|c|c|}
\hline \multirow[b]{2}{*}{ Indicators } & \multirow{2}{*}{$\begin{array}{l}\text { Cereals } \\
\text { and } \\
\text { legumes }\end{array}$} & \multicolumn{3}{|c|}{ Including } & \multirow{2}{*}{$\begin{array}{c}\text { Sugar } \\
\text { beet }\end{array}$} & \multirow[b]{2}{*}{ Sunflower } & \multicolumn{2}{|c|}{ Potatoes } & \multicolumn{2}{|c|}{ Vegetables } \\
\hline & & wheat & barley & corn & & & total & $\begin{array}{c}\text { in } \\
\text { households }\end{array}$ & total & in households \\
\hline \multicolumn{11}{|c|}{ Gross yield (million tons) } \\
\hline $2008-2012$ & 86.3 & 52.2 & 16.1 & 5.8 & 33.8 & 7.4 & 28.7 & 23.3 & 13.6 & 9.5 \\
\hline $2013-2017$ & 111.8 & 66.6 & 18.4 & 12.9 & 43.0 & 10.1 & 31.2 & 24.7 & 15.9 & 10.6 \\
\hline $\begin{array}{l}\text { The second } \\
\text { period to the } \\
\text { first period, } \%\end{array}$ & 129.5 & 127.6 & 114.3 & 222.4 & 127.2 & 136.5 & 108.7 & 106.0 & 117.0 & 111.6 \\
\hline \multicolumn{11}{|c|}{ Arable area (ths. hectars) } \\
\hline $2008-2012$ & 45100 & 26442 & 8514 & 1633 & 1047 & 6738 & 2194 & 1853 & 667 & 497 \\
\hline $2013-2017$ & 46694 & 27046 & 8728 & 2766 & 1030 & 7354 & 2067 & 1736 & 681 & 501 \\
\hline $\begin{array}{l}\text { The second } \\
\text { period to the } \\
\text { first period, \% }\end{array}$ & 103.5 & 102.3 & 102.5 & 169.4 & 98.4 & 109.1 & 94.2 & 93.8 & 102.1 & 100.8 \\
\hline \multicolumn{11}{|c|}{ Crop productivity (per hectar) } \\
\hline $2008-2012$ & 19.4 & 19.7 & 18.8 & 35.5 & 322.8 & 11.0 & 132.6 & 126.2 & 203.2 & 190.7 \\
\hline $2013-2017$ & 23.9 & 24.6 & 21.0 & 46.7 & 417.5 & 13.7 & 150.9 & 142.1 & 233.9 & 211.1 \\
\hline $\begin{array}{l}\text { The second } \\
\text { period to the } \\
\text { first period, \% }\end{array}$ & 123.2 & 124.9 & 111.7 & 131.5 & 129.3 & 124.5 & 113.8 & 112.6 & 115.1 & 110.7 \\
\hline
\end{tabular}

* Calculated by authors based on official data (Agriculture, hunting and forestry in Russia. Federal State Statistics Service (FSSS). Statistical collection (SC). Electronic versions 2009, 2011, 2013, 2015; Russian statistical yearbook. FSSS-SC. Electronic versions 2008-2018)

The study of the balance of nutrients in the conditions of modern Russia is devoted to numerous studies. Sychev and Saffran (2017) exploring the balance of nutrients in agriculture in Russia for the period from 1966 to 2015. in particular, they note that since the 1990s, the use of mineral fertilizers has sharply decreased, as a result of which the balance of nutrients began to take shape with a significant excess of the removal over their input into the soil. Sychev et al. (2016) expressed the opinion that, the annual decline in the yield of winter wheat and spring barley is within 1 centner/ha is the result of the imbalance of nutrients that had arisen since the 1990s in favor of their removal throughout the country. Further, these authors note that if the situation does not change, the crop shortage will increase. Monastyrsky et al. (2016) emphasizes that the immediate restoration of scientifically-based doses of the use of mineral fertilizers and plant protection products is a crucial condition for food safety. The nature of the current imbalance in favor of the removal of nutrients, including particular regions of Russia, is also reflected in (Shafran, 2016; Krasnitsky et al., 2018; Chekmarev, 2018; Yakovlev et al., 2018).

This article aims to construct and analyze the balance of the main nutrients in Russia in the context of crops over the past 10 years. Constructing balances over five-year periods, on the one hand, helps eliminate the effect on the meteorological conditions of individual years on production volumes, and on the other, allows comparing balances over two periods, including major crops and nutrient types. In addition, the aim of the 
work is to establish the causes of the imbalance of nutrients and to propose an organizational and financial mechanism for its elimination by increasing the volume of applied fertilizers.

\section{Material and Methods}

The object of the study is the balance of nutrients for main crops, the cultivation of which took place in Russia from 2008 to 2017. As an information base we used data from the official statistical compilations of Federal State Statistical Service, as well as the standards for the removal of nutrients from the harvested crop, as indicated in the relevant educational and scientific literature. The research methodology includes the analysis of time series through a system of absolute and relative indicators, as well as constructive calculations. In particular:

The absolute increase shows by how many units of measure the value of the indicator has changed in the current period compared to the previous one

$$
A_{i}=y_{i}-y_{i-1}
$$

The growth coefficient shows how many times the value of the indicator has changed in the current period compared to the previous one

$$
K_{i}=\frac{y_{i}}{y_{i-1}}
$$

The percentage growth rate shows how many percent the value of the indicator has changed in the current period compared to the previous one.

$$
T_{i}=\frac{A_{i}}{y_{i-1}} \times 100
$$

where;

$\mathrm{y}_{\mathrm{i}}$ - value of the studied indicator in the current period

$\mathrm{y}_{\mathrm{i}-1}$ - value of the studied indicator in the previous period

The use of the computational-constructive method made it possible to calculate the predictable amount of a fund of deductions from the sale of grain crops for export, aimed at restoring effective soil fertility:

$$
\mathrm{F}=\mathrm{P} \times \mathrm{N} \times \mathrm{Q}
$$

$P$ - average price of exported grain, USD per ton (in the proposed calculations - \$200)

$\mathrm{N}$ - a standard proposed by the authors of contributions to the fund for the restoration of natural soil

fertility in the amount of $5 \%$

$\mathrm{Q}$ - the amount of exported grain (in the example - 30 million tons)

\section{Results and Discussion}

On the basis of data on the gross yield of main crops (Table 1) and the standards for the removal of nutrients with the unit of the harvested crops (Kidin and Torshin, 2015) the calculated volume of the annual production removal of nutrients and their removal with the main products is presented in Table 2 . About 60 - 70\% of the total production removal of nutrients accounted for wheat and barley sowing, about $20 \%$ for sunflower sowing. With the harvest of corn and sugar beet, $7-10 \%$ of the total production removal was made. Plantingof potatoes and vegetables account for an insignificant proportion of the removal, due to the fact that the calculation was made only for sowing in agricultural organizations and farms. As for the structure of the removal of nutrients with the main products, by crops it generally corresponds to the structure of production removal, with the exception of the share of sunflower, which decreases to $10-12 \%$.

It should also be especially emphasized that the volume of both production removal and removal with the main crops in the second period increased in proportion to the growth of their gross harvests. For individual nutrients, calculations of the volumes of production removal and removal with the main products are presented in Table 3.

In the structure of production removal of nutrients, about $50 \%$ is potassium, nitrogen is about $35 \%$, and the remaining $15 \%$ is phosphorus. The structure of removal with the final products is different: up to $58 \%$ is nitrogen, about $25 \%$ is phosphorus and the remaining $16-17 \%$ is potassium. 
Table 2. Average removal of nutrients with crop yields in Russia per year by periods (th. tonnes of active substance)

\begin{tabular}{|c|c|c|c|}
\hline \multirow{2}{*}{ Group of crops and crops } & \multicolumn{2}{|c|}{ Period (five years) } & \multirow{2}{*}{$\begin{array}{l}\text { The second period to the } \\
\text { first period, } \%\end{array}$} \\
\hline & 2008-2012 & $2013-2017$ & \\
\hline \multicolumn{4}{|l|}{ Wheat + Barley* } \\
\hline production removal & 4888 & 5756 & 117.8 \\
\hline grain removal & 2352 & 2916 & 124.0 \\
\hline \multicolumn{4}{|l|}{ Corn } \\
\hline production removal & 485 & 1048 & 216.1 \\
\hline grain removal & 171 & 374 & 218.7 \\
\hline \multicolumn{4}{|l|}{ Sugar beet } \\
\hline production removal & 510 & 635 & 124.5 \\
\hline root vegetable removal & 218 & 275 & 126.1 \\
\hline \multicolumn{4}{|l|}{ Sunflower } \\
\hline production removal & 1543 & 2090 & 135.4 \\
\hline seed removal & 391 & 536 & 137.1 \\
\hline \multicolumn{4}{|l|}{ Potatoes ** } \\
\hline production removal & 82 & 97 & 118.3 \\
\hline tuber removal & 51 & 62 & 121.6 \\
\hline \multicolumn{4}{|l|}{ Vegetables $* * *$} \\
\hline production removal & 43 & 56 & 130.2 \\
\hline \multicolumn{4}{|l|}{ For all crops } \\
\hline $\begin{array}{l}\text { production removal } \\
\text { removal with the main products }\end{array}$ & 7551 & 9682 & 128.2 \\
\hline (without vegetables) & 3183 & 4064 & 127.7 \\
\hline
\end{tabular}

Table 3. Average production removal of nutrients and removal with the main crops for the year (ths tons of active substance)

\begin{tabular}{lccc}
\hline \multirow{2}{*}{ Nutrients } & \multicolumn{2}{c}{ Period } & $\begin{array}{c}\text { The second period to the first } \\
\text { period, } \%\end{array}$ \\
\cline { 2 - 4 } & $2008-2012$ & 2013-2017 & 130.1 \\
\hline Nitrogen & \multicolumn{2}{c}{ Production removal } & 119.4 \\
Phosphorus & 2500 & 3643 & 129.7 \\
Potassium & 1208 & 1443 & 128.2 \\
Total & 3543 & 4596 & 139.1 \\
\hline & 7551 & 9682 & 126.2 \\
Nitrogen & Removal with the main crops & 112.4 \\
Phosphorus & 1750 & 2434 & 130.8 \\
Totassium & 862 & 1088 & 642 \\
\hline
\end{tabular}

During the second five-year, the production removal of nitrogen and potassium increased most intensely, and with the main products nitrogen and phosphorus increased. Based on the average yield obtained by periods, the removal of nutrients per 1 hectare of sowing of the respective crops is presented in Table 4 .

The largest volume of production removal from 1 hectare of sowing in both periods occurred in sugar beet, corn and vegetables, the smallest in wheat and barley. In the same approximate ratio are cultures for the removal of the direct products. The increase in yields for all crops in the second five-year period led to an annual increase in nutrient removal in the same proportion.

Table 5 presents data on the application in the studied periods of mineral and organic fertilizers, as well as other measures aimed at improving the effective fertility of the soil. The materials of this table show, first of all, that despite the slight increase in the number of mineral fertilizers introduced in the second period (with the exception of potash fertilizers), more than half of the arable areas are still not fertilized. 
Table 4. The total removal of nutrients from 1 hectare of crops sowing (kilograms of active substance)

\begin{tabular}{|c|c|c|c|}
\hline \multirow{2}{*}{ Group of crops and crops } & \multicolumn{2}{|c|}{ On average per year by period } & \multirow{2}{*}{$\begin{array}{l}\text { The second period to the first } \\
\text { period, } \%\end{array}$} \\
\hline & 2008-2012 & $2013-2017$ & \\
\hline \multicolumn{4}{|l|}{ Wheat + Barley * } \\
\hline production removal & 140 & 161 & 115.0 \\
\hline grain removal & 67 & 82 & 122.4 \\
\hline \multicolumn{4}{|l|}{ Corn } \\
\hline production removal & 297 & 379 & 127.6 \\
\hline grain removal & 105 & 135 & 128.6 \\
\hline \multicolumn{4}{|l|}{ Sugar beet } \\
\hline production removal & 487 & 617 & 126.7 \\
\hline root vegetable removal & 209 & 267 & 127.8 \\
\hline \multicolumn{4}{|l|}{ Sunflower } \\
\hline production removal & 229 & 284 & 124.0 \\
\hline seed removal & 58 & 73 & 125.9 \\
\hline \multicolumn{4}{|l|}{ Potatoes ** } \\
\hline production removal & 240 & 294 & 122.5 \\
\hline tuber removal & 151 & 188 & 124.5 \\
\hline \multicolumn{4}{|l|}{ Vegetables $* * *$} \\
\hline production removal & 255 & 312 & 122.4 \\
\hline \multicolumn{4}{|c|}{$\begin{array}{l}* \text { crops are combined, because according to them the removal from a unit of production is approximately the same; }{ }^{* *} \text { for potatoes and } \\
\text { vegetables, the calculation was made only for agricultural organizations and farms; }{ }^{* *} \text { for vegetables, the calculation for the final produc } \\
\text { was not made, due to the large variation of this indicator for individual vegetable crops }\end{array}$} \\
\hline \multicolumn{4}{|c|}{$\begin{array}{l}\text { Table } 5 \text {. Indicators of measures to improve the effective fertility of land in Russia from } 2008 \text { to } 2017 \text { over five years (on } \\
\text { average per year) }\end{array}$} \\
\hline \multirow{2}{*}{ Indicators } & \multicolumn{2}{|c|}{ Period (five years) } & The second period to the \\
\hline & $2008-2017$ & $2013-2017$ & first period, $\%$ \\
\hline \multicolumn{4}{|c|}{ Mineral fertilizers (million tons of active substance) } \\
\hline $\begin{array}{l}\text { Total } \\
\text { including: }\end{array}$ & 2.42 & 2.66 & 109.9 \\
\hline Nitrogen & 1.52 & 1.66 & 109.2 \\
\hline Phosphorus & 0.50 & 0.61 & 122.0 \\
\hline Potassium & 0.40 & 0.39 & 97.5 \\
\hline \multicolumn{4}{|c|}{ Mineral fertilizers applied per 1 hectare (kg of active substance): } \\
\hline the total sowing area & 37 & 45 & 121.6 \\
\hline cereal sowing & 41 & 47 & 114.6 \\
\hline sugar beet sowing & 270 & 277 & 102.6 \\
\hline Sunflower sowing & 24 & 30 & 125.0 \\
\hline planting of potatoes & 257 & 316 & 123.0 \\
\hline planting of vegetables & 156 & 181 & 116.0 \\
\hline \multicolumn{4}{|l|}{ Organic fertilizer applied } \\
\hline \multicolumn{4}{|l|}{ total } \\
\hline in physical weight (mln tons) & 53.0 & 62.7 & 118.3 \\
\hline in active substance (ths tons) & 715 & 847 & 118.3 \\
\hline \multicolumn{4}{|l|}{ on 1 ha of sowing of all crops } \\
\hline in physical weight (tones) & 1.0 & 1.2 & 120.0 \\
\hline in active substance $(\mathrm{kg})$ & 9.4 & 10.7 & 113.8 \\
\hline \multicolumn{4}{|c|}{ The proportion of the fertilized area (\%) } \\
\hline by mineral fertilizers & 44.4 & 48.4 & +4.0 \\
\hline by organic fertilizer & 7.1 & 8.2 & +1.4 \\
\hline Liming acid soils (mln. ha) & 0.24 & 0.22 & 91.6 \\
\hline Lime flour applied & & & \\
\hline total (mln tons) & 2.06 & 2.10 & 101.9 \\
\hline Per 1 ha (tons ) & 8.3 & 8.9 & 107.2 \\
\hline $\begin{array}{l}\text { Phosphoritization of acidic } \\
\text { (thousand hectares) }\end{array}$ & 8.7 & 16.8 & 224.0 \\
\hline
\end{tabular}

The volume of work on soil deoxidation, which occupy tens of millions of hectares in Russia, is absolutely insufficient and not changing in dynamics. Let's compare the removal of nutrients from 1 hectare of crops 
(Table 4) and fertilization to this area (Table 5) by crops over five years. We present this comparison in Table 6.

Table 6. Removal with a harvest and application of nutrients per 1 hectare of sowing on average per year over five years ( $\mathrm{kg}$ of active substance)

\begin{tabular}{|c|c|c|c|c|c|c|}
\hline \multirow{3}{*}{$\begin{array}{l}\text { Group of crops and } \\
\text { crops }\end{array}$} & \multicolumn{6}{|c|}{ Period } \\
\hline & \multicolumn{3}{|c|}{$2008-2012$} & \multicolumn{3}{|c|}{$2013-2017$} \\
\hline & Removal & Application & $\begin{array}{l}\text { Application to } \\
\text { removal, } \%\end{array}$ & Removal & Application & $\begin{array}{l}\text { Application to } \\
\text { removal, } \%\end{array}$ \\
\hline \multicolumn{7}{|c|}{ Wheat + Barley } \\
\hline production removal & 140 & 41 & 29.3 & 161 & 47 & 29.2 \\
\hline grain removal & 67 & & & 82 & & \\
\hline \multicolumn{7}{|c|}{ Corn* } \\
\hline production removal & 297 & $60^{*}$ & 20.2 & 379 & $60^{*}$ & 15.8 \\
\hline grain removal & 105 & & & 135 & & \\
\hline \multicolumn{7}{|c|}{ Sugar beet } \\
\hline production removal & 487 & 270 & 55.4 & 617 & 277 & 44.9 \\
\hline root vegetable removal & 209 & & & 267 & & \\
\hline \multicolumn{7}{|c|}{ Sunflower } \\
\hline production removal & 229 & 24 & 10.5 & 284 & 30 & 10.6 \\
\hline seed removal & 58 & & & 73 & & \\
\hline \multicolumn{7}{|c|}{ Potatoes } \\
\hline production removal & 240 & 257 & 107.1 & 294 & 316 & 107.5 \\
\hline tuber removal & 151 & & & 188 & & \\
\hline \multicolumn{7}{|c|}{ Vegetables } \\
\hline production removal & 255 & 156 & 61.2 & 312 & 181 & 58.0 \\
\hline
\end{tabular}

* approximate value, obtained from literary sources for the Southern and North Caucasian federal districts, which account for about $60 \%$ of planting of crops

Only one tenth of the nutrients removed with the sunflower crop is compensated by the mineral fertilizers applied. For corn, the sixth-fifth part is compensated, for wheat and barley no more than $30 \%$, for sugar beet and vegetables about a half. Only for potatoes with its very low productivity, fertilizers compensate for the entire removal of nutrients. It should be emphasized that in the second five-year period, the proportion of nutrients compensated by fertilizers for most crops decreases and only the sunflower remains the same, about $10 \%$.

This leads to a fundamental conclusion: The growth of gross harvest of agricultural crops achieved in recent years is ensured, above all, by the use of natural soil fertility. Therefore, with the continued decrease in compensation of natural fertility by fertilizers, in the long term there will inevitably be a decrease in the natural and, consequently, effective soil fertility and, as a result, a decrease in the volume of crop production. Comparison of the volumes of nutrients removed with the crop and applied with mineral fertilizers according to their types is presented in Table 7.

Table 7. Annual removal and application of nutrients by their types in Russia, as a whole (ths. tons of active substance)

\begin{tabular}{lcccccc}
\hline & \multicolumn{5}{c}{ Period } \\
\cline { 2 - 7 } Nutrients & $\begin{array}{c}\text { Production } \\
\text { removal }\end{array}$ & $\begin{array}{c}\text { Removal with } \\
\text { direct products }\end{array}$ & Application & $\begin{array}{c}\text { Production } \\
\text { removal }\end{array}$ & $\begin{array}{c}\text { Removal with } \\
\text { direct products }\end{array}$ & Application \\
\hline Nitrogen & 2800 & 1750 & 1520 & 3643 & 2434 & 1660 \\
Phosphorus & 1208 & 862 & 500 & 1443 & 1088 & 610 \\
Potassium & 3543 & 571 & 400 & 4596 & 642 & 390 \\
Total & 7551 & 3183 & 2420 & 9682 & 4164 & 2660 \\
\hline
\end{tabular}

The largest difference between the production removal and nutrients applied is in potassium: about 3 million tons in the first five years and 4 million tons in the second. For nitrogen the deficit was about $1.3 \mathrm{mln}$. tons of active substance in the first five years and $1.8 \mathrm{mln}$. tons of active substance in the second. For phosphorus, the difference between removal and application is the lowest: 700 thousand tons in the first five years, and about 800 thousand tons in the second. It is worth emphasizing that in the second five-year period, the difference in favor of the removal of all nutrients increased.

After what has been said, the question is naturally: does the Russian industry have the ability to eliminate as quickly as possible the difference between the removal and application of nutrients and, therefore, prevent the degradation of Russian soils? Table 8 presents data on the annual production of mineral fertilizers in 
Russia over the past 10 years. This table also compares the amounts of mineral fertilizers applied and produced. The production of mineral fertilizers in the last 5 years has increased in all types of fertilizers, but only the seventh part of fertilizers produced in Russia were applied, and nitrogen and phosphorus, is one fifth and one sixth. We have a paradoxical picture that is absolutely unacceptable for common sense: we produce fertilizers, but do not apply them, constantly worsening the natural fertility of the soil.

Mineral fertilizers produced in Russia at the expense of irreplaceable resources are exported. According to our calculations, in the last 5 years, on average, 14.8 million tons of mineral fertilizers were exported per year, including 4.7 million tons of nitrogen fertilizers, 4.3 million tons of mixed fertilizers and 5.8 million tons of potash fertilize. If the exported fertilizers were applied in Russia, then each hectare of arable land would receive an additional $186 \mathrm{~kg}$ of active substance of fertilizer. This is in principle (additional calculations are necessary, of course) would be enough to cover the removal of nutrients at the level of crop productivity achieved. Higher productivity levels will require higher doses of fertilizer.

Table 8. Production of mineral fertilizers in Russia on average for the year, the share of the volume of applied mineral fertilizers of the produced

\begin{tabular}{|c|c|c|c|}
\hline \multirow{2}{*}{ Type of fertilizers } & \multicolumn{2}{|c|}{ Period } & \multirow{2}{*}{$\begin{array}{l}\text { The second period to the } \\
\text { first period, } \%\end{array}$} \\
\hline & $2008-2012$ & 2013-2017 & \\
\hline \multicolumn{4}{|c|}{ Produced (million tons of active substance) } \\
\hline Nitrogen & 7.56 & 8.90 & 117.7 \\
\hline Phosphorus & 2.92 & 3.40 & 116.4 \\
\hline Potassium & 6.60 & 8.00 & 121.2 \\
\hline Total & 17.08 & 20.03 & 117.3 \\
\hline \multicolumn{4}{|c|}{ Application to production of fertilizers (Table 7), \% } \\
\hline Nitrogen & 20.1 & 18.6 & -1.5 \\
\hline Phosphorus & 17.1 & 17.9 & -0.8 \\
\hline Potassium & 6.1 & 4.9 & -1.2 \\
\hline Total & 14.2 & 13.3 & -0.9 \\
\hline
\end{tabular}

It is logical to assume that the reason that the produced mineral fertilizers are sent for export is the difference in prices (export and domestic), in the substantial benefit of export. Due to the lack of systematic data for comparing these prices, we present calculations for 2010 and 2014. Export prices: (in terms of rubles at the average annual exchange rate) generally refer to nitrogen, potash and mixed fertilizers, and domestic - to certain types of fertilizers with their classification into nitrogen, potash, mixed (Table 9).

Table 9. Export and domestic prices for mineral fertilizers (rubles per ton in physical weight) (Anonymous, 2018b)*

\begin{tabular}{llcc}
\hline Type of the price & Types of the fertilizers & 2010 & 2014 \\
\hline Export & Nitrogen & 6070 & 9612 \\
& Potassium & 8632 & 9288 \\
& Mixed & 10462 & 13212 \\
\hline \multirow{5}{*}{ Nitrogen } & & - \\
\cline { 2 - 4 } & Ammonium nitrate & 7297 & - \\
& Ammonium sulphate & 5142 & 11500 \\
& Liquid ammonia & 4908 & 14299 \\
\cline { 2 - 4 } & Carbamide & 9139 & 10434 \\
\cline { 2 - 4 } & Potassium & & 17750 \\
\cline { 2 - 4 } & Mixed & & 18992 \\
\cline { 2 - 4 } & Nitro Ammophos & 8652 & 15209 \\
& Ammophos & 14364 & 14925 \\
& Azofoska & 11627 & 18275 \\
& Sulfa Ammophos & 10200 & 18041 \\
\hline
\end{tabular}

* Calculated by authors based on official data (Trade in Russia. Federal State Statistics Service. Statistical collection. Electronic versions 2009,2011,2013,2015

From the data of this table 9, it follows that both export and domestic prices have increased over four years, for some types of fertilizers by 1.5 times, but the main conclusion is that export prices are not higher than domestic ones, and even lower for nitrogen and potash. Consequently, the difference in prices in favor of export should not be considered as a factor of its advantage. Obviously, the question is either in the absence 
of Russia's agricultural producers of financial resources for the purchase of fertilizers or in their dismissive, selfish attitude to such an important resource as soil fertility.

According to our calculations, the average annual revenue of exporters of fertilizers for 2012-2016 amounted to 9010.6 million USD. In terms of rubles at an average rate of 60 rubles. per dollar annual revenue amounted to 540.636 billion rubles. If the state withdraw $10 \%$ from this revenue for the replenishment the fund for the conservation of natural fertility offered in this article, the amount of its annual replenishment will be 54.064 billion rubles. Then, even at the maximum price of 20,000 rubles per ton, the farmers will additionally get 2,730.3 million tons of mineral fertilizers, or, in terms of 1 ha of the entire arable area, about $35 \mathrm{~kg}$.

Along with the export of mineral fertilizers, in recent years, exports of agricultural products, primarily grain, have been growing rapidly. But, since it was established that the growth of gross grain harvest in modern Russia occurs primarily due to a decrease in natural soil fertility, an increase in grain exports actually means the alienation of the country's not replenished natural resources in the form of soil fertility elements. Table 10 , based on the amount of nutrients that are not replenished by the application of mineral fertilizers, presents the calculation of the volumes of their alienation abroad.

Table 10. Exports of grain and nutrients from Russia over five years (on average per year)

\begin{tabular}{lccc}
\hline Indicators & On average per year for five years (period) & $\begin{array}{c}\text { The second period to the } \\
\text { first period, } \%\end{array}$ \\
\hline Exported grain (thousand tons) & $2008-2012$ & $2013-2017$ & 160.1 \\
\hline Wheat & 14345 & 22971 & 149.6 \\
Barley & 2414 & 3612 & by 4.3 times \\
Corn & 943 & 4059 & 92.2 \\
\hline Alienated overseas elements of natural fertility by 1 ton of exported products (kg of active substance) \\
\hline Wheat & 50.2 & 46.3 & 103.2 \\
Barley & 52.6 & 54.3 & 102.2 \\
\hline Alienated overseas elements of natural fertility from the entire export (tons of active substance) & 147.7 \\
\hline Wheat & 720119 & 1063557 & 154.5 \\
Barley & 126976 & 196132 & by 4.4 times \\
Corn & 62992 & 277230 & 168.9 \\
\hline
\end{tabular}

With the alienation of nutrients from 1 ton of exported products remaining in general in the second period, due to the growth of grain exports, the overall increase in the volumes of nutrients alienated for abroad increased almost 1.69 times and reached 1.537 million tons of active substance, that is about $70 \%$ of the amount of fertilizer applied for grain. In our opinion, export supplies of grain should be another source of preserving the natural fertility of the land in Russia. Such a proposal is logical, including from the point of view of export: exporters should think not only about the present profit, but also about the possibility of its stable receipt in the future, which is excluded when effective soil fertility is reduced. With a modern export price of 1 ton of grain not lower than USD 200 per ton, exporters should, in our opinion, transfer at least \$10 to the fund to support natural soil fertility. If we proceed from the average annual volume of grain exports in recent years in the amount of at least 30 million tons, the amount of deductions will be 300 million USD, and at the rate of 60 rubles for dollar it will be about 18 billion rubles. The use of these deductions, according to our approximate calculations, will allow increasing the doses of fertilizer application for cereals by at least $30-40 \mathrm{~kg}$ of active substance per 1 hectare of the arable area.

\section{Conclusion}

The growth of gross harvests of major crops in Russia in recent years has been accompanied by a growing imbalance between the removal of nutrients from the crop and their application with fertilizers. Thus, there is an intensive decrease in the effective fertility of the soil, which, can develop into their degradation while maintaining this process. Instead of all the expected growth in crop production, the result will be an accelerated fall. Of course, this conclusion should be supported and differentiated by regional studies, including agrochemical soil monitoring.

To reduce, and in the future complete elimination of imbalance of nutrients in the soil, along with state support for the application of mineral fertilizers by economic entities, in our opinion, the immediate creation 
of a special fund for the conservation of soil fertility should be relevant. The main sources of replenishment of this fund can be deductions from export earnings from the supply of mineral fertilizers and grain abroad.

\section{References}

Anonymous, 2018a. Agriculture, hunting and hunting, forestry in Russia. Federal State Statistics Service. Statistical collection. Electronic versions 2009, 2011, 2013, 2015 [in Russian].

Anonymous, 2018b. Trade in Russia. Federal State Statistics Service. Statistical collection. Electronic versions 2009,2011,2013,2015, 2017. Russian statistical yearbook. Federal State Statistics Service. Statistical collection. Electronic versions 2008-2018 [in Russian].

Chekmarev, P.A., 2018. Fertility recovery is a fundament of sustainable development of Russian Agribusiness. Plodorodie 1: 2-4 [in Russian].

Kidin, V.V., Torshin, S.P., 2015. Agrochemistry. Prospectus, Moscow. 619p. [in Russian].

Korchagin, V.I., Koshelev, Yu.A., Myazin, N.G., 2016. Monitoring of agrochemical parameters of soil fertility and the yield of the main agricultural crops in Voronezh oblast. Plodorodie 3: 10-12 [in Russian].

Krasnitsky, V.M., Schmidt, A.G., Tsyrk, A.F., 2018. Agrochemical characteristics of agricultural soils and effectiveness of agricultural production in Omsk region. Plodorodie 2: 4-5 [in Russian].

Monastyrsky, O.A., Glinushkin, A.P., Sokolov, M.S., 2016 The problem of ensuring food security of Russia and ways to solve it. Agricultural Chemistry 11: 3-11 [in Russian].

Shafran, S.A., 2016. Soil fertility dynamics of the Non-chernozem zone and its reserves. Agricultural Chemistry 8: 3-10 [in Russian].

Sychev, V.G., Saffran, S.A., 2017. Balance of nutrients in Russian agriculture. Plodorodie 1: 1-4 [in Russian] .

Sychev, VG, Shafran, S.A., Dukhanina, T.M., 2016. Prognosis of the demands of Russian agriculture for mineral fertilizers to 2030. Plodorodie 2: 5-7 [in Russian]

Yakovlev, AS, Makarov, OA, Evdokimova, MV, Ogorodnikov, S.S., 2018. Land Degradation and Problems of Sustainable Development. Eurasian Soil Science (ПОЧВОВЕДЕНИЕ) 9: 1167-1174 [in Russian]. 